\title{
In the name of the father. A personal dostoevskian myth
}

\author{
Călin-Horia Bârleanu ${ }^{\mathbf{A} *}$ \\ Faculty of Letters and Communication Sciences, "Ștefan cel Mare" University, Str. Universitățiii 13, 720229 Suceava, Romania
}

\begin{abstract}
Article info
History:

Received February 26, 2021

Accepted April 1, 2021

Published August 18, 2021

Keywords:

psychocritics

paternal figure

hero

complex

Abstract

Dostoevsky's name is already linked to an almost equal number of myths concerning his works, as his life. This fact does not, however, take away from his resplendence, since the true dimension of his great works is still revealing its secrets and meanings. Focused in many of his masterpieces on the paternal figure (manifestly projected or, sometimes, expressed in a latent register), the writer remains captive to his own abyss, from which he derives his creativity, undoubtedly distilling his torment - a torment, it seems, he experienced constantly throughout his life. The symbolic weaving of his work reveals a true thematic network in which the image of the father dominates akin to a god - usually an indifferent and absent one.
\end{abstract}

It was Charles Mauron's psychocriticism which opened, beyond Freudian psychoanalytic suggestions, in 1962, the path to a new formula for reading and understanding both the text and its creator. The proposal of the French essayist and critic aroused, in a much more tolerant cultural space, the most vivid reactions, especially against the background of a sustained campaign, led by Jaques Lacan, on the dimensions and applicability of psychoanalysis. In comparison, in the year in which there appeared in Romania Mibail Eminescu from a psychoanalytic point of view (Vlad, 1932), he reactions went far beyond the limits of academic or research-specific discourse. Without anchors which could have narrowed or limited, in any way, the horizon of knowledge of the literary work, especially since psychoanalysis has demonstrated the ability to discover through its tools, new ways of interpretation, perspectives and concepts (such as the existence of an instinctual life, failed acts or the influence of the unconscious on the communication process), psychocritics enjoyed a fertile context, waiting for a new language which would ultimately provide a voice to those interested in the deep dimensions of the work of art.

Obviously, a psychocritical approach in any literary work must be supported, precisely for the effective realization of the overlapping of texts and the revelation of obsessive figures that build the personal myth, through a form of access to the writer's life, where creation remains project and finds itself in a permanent embryonic state. In Dostoevsky's case, an important advantage comes through the translation work of Leonte Ivanov (Dostoevsky, 2018), a researcher and professor from Iasi. Letters I (1837-1859), covering perhaps the most important period in the life of the adolescent and young man who would become the most famous and influential Russian writer, show an ideological pattern which places the father figure in an area where communication is done through pre-established brands which evoke a strong paternal authority. Almost without exception, the young Feodor Mihailovici'letters end in the same note, through which we should see both a specific social pattern of the time, but also a form of dependence which the adolescent felt as a pressure. For example, a letter from 1837, when Dostoevsky was sixteen, concludes, "With sincere respect and filial affection, we have the honor to be your children" (Dostoevsky, 2018, p. 43) (referring to his brother Mikhail) or, in another letter, from the same year "With deep respect and kind regards, always yours, Mikhail and Feodor Dostoevsky, who sincerely love you.” (p. 46).

The economic reasons, to which the letters most often refer, the young people having different needs specific to the school, frame the epistolary style destined for the father in a very rigid mold, which disappears completely in any other letter. So striking is the difference between the letters that Feodor Pavlovich

*Email address: calin.barleanu@gmail.com. 
sends to his father and those sent to his brother, that the invoked filial love, or respect, always deep and "until the end of times" (Dostoevsky, 2018, p. 50) begins to show other dimensions. If we were to analyze the image of fatherhood, including the later Dostoevsky's work, we are faced with a real complex which finds an answer, initially, in the haste with which the young man chooses to abandon military studies as his father's death frees him from moral obstacles. Apart from the fact that after the death of Mikhail Andreevich Dostoevsky the young man refers only a few times to the memory of his father, he writes to his brother, when he was still alive, at only seventeen, in 1838, words which, in deep contrast to absolute filial love and respect, reflect another reality: "I feel sorry for our poor father! Strange character! [...] But did you notice? Dad doesn't know the world at all: he had lived in it for fifty years and was left with the same opinion about people [...]. Happy ignorance." (p. 74).

The difference between the styles that the young Dostoevsky uses, in his letters to his father and in those to his brother, is not only visible, but even striking, in many places. The freedom to express himself and the authenticity of the expressed feelings are reflected with simplicity in each line, without exaggerated effusions or meant to convince, demonstratively, that the written ones are also real. The letters to his brother really bear the imprint of unconditional affection: "Oh, how long, how long time has passed since I heven't written to you, my dear brother ... Disgusting examination!” (Dostoevsky, 2018, p. 70). The permanent invitation to write back to him, which accompanies each letter addressed to Mihail, supports the adolescent's need to stay in touch with his family, to freely communicate his true and, for the time being, hidden feelings and aspirations for the future.

For most of his commentators, Dostoevsky's literary work has remained a landmark, especially in terms of the conflict with the paternal figure. The analytical discourse sustained by psychocriticism or psychoanalysis has been oriented, in innumerable pages already, towards the way in which the paternal authority is constructed at the level of the fiction of the text. The fiction that both psychocriticism and psychoanalysis have written about, referring to the relationship with artists' ability to construct images, fantasies, or, in other words, to dream with their eyes open, has an important root in the unconscious, where, according to Jungian psychoanalysis, there are the fundamental myths of humanity, the conflicts and intimate themes of human existence, in the form of cultural symbols and archetypes.

Regarding the way in which paternal authority was perceived in the great universal literature (figures of gods, echoes of unconscious life, often harmed by people's love or freedom to act, thus frustrating their sense of superiority and immortality), the Oedipus complex has always been discussed, by psychoanalytic approaches, through the specific conflict with the paternal figure. Despite the fact that, from the famous Freudian concept, only a truncated understanding of human unconscious dynamics has remained to this day, the specific conflicting component cannot be ignored. In this sense, reducing the Oedipal complex to the boy's love for his mother is only a mistake, especially by ignoring the dimension of the collective unconscious. Mircea Eliade saw in the symbol of the mother, central in the myth, but also in the structure of the psychological complex, an echo for what psychoanalysis called the pulsation of life: "The Image of the Mother itself is true, and not one mother or another [and] this desire expresses several things at the same time, because she is the desire to re-enter the blissful state of the living Matter" (Eliade, 1994, p. 18-19).

Published in 1875, the novel translated into Romanian with the title The Adolescent has remained, as part of the great Dostoevsky novels, certainly the most controversial. The debate comes precisely from the fact that any metaphysical relaxation, specific to the writer's literature, is almost missing here, no doubt also through the way the central character is projected. In the form of a process of remembrance, "I have begun to write down this story of my first steps on the road to life ..." (Dostoevsky, 2019, p. 7), the young Arkadi Andreevich sets from the very beginning the tone of the whole novel, touched by frustration, and the psychology of what Marthe Robert called the "bastard's novel": "I pass, therefore, as his legitimate son, though I am a bastard by all means" (p. 8).

Legally the son of a former serf, Makar Ivanov Dolgoruki, he is raised by an absent father, landowner Varsilov, on whom the teenager focuses almost most of his energies. Abandoned, therefore, by his natural father, he is almost completely ignored by the one in whose company he grows up, although the presence 
of paternal authority is almost completely absent from Arkadi's life. Under the imprint of a repeated abandonment, the young man develops a strong opposition to the image of fatherhood, visible through direct details: "rarely has anyone been so angry with his name as I have been since I was born." (Dostoevsky, 2019, p. 9).

We will therefore observe that Dostoevsky does not refrain from putting the psychological reflexes of the hero in the clearest possible light of the simplest reading approach. His experiences, limited, but with a strong impact on self-esteem and the way he perceives himself as an entity, unwanted or repeatedly abandoned, build a morbid, sometimes even masochistic discourse supported by the pulsation of death. Trapped between the two male figures, equally absent, Arkadi chooses, however, as a landmark, the one that seems more compatible with his ideological universe. As proof, in the end, the father and the son end up having feelings for the same woman. "Versilov, my father, wh om I had seen only once at the age of ten" (Dostoevsky, 2019, p. 19) is the one on whom the child's imagination throws itself to fill not the gaps, but the great void [s.n.], representing the image of paternity. Perceived as "cold and arrogant, contemptuous and indifferent to me ..." (p. 19), Versilov seems to be, in fact, only to a small extent like the way his son perceives him.

The tireless search for his father's figure, as a psychological need from which he was repeatedly deprived, brings Arkadi closer to the old Prince Sokolski. The Dostoevsky imaginary also filters the archetypes specific to the collective unconscious, because the figure of the wise old man, present in all cultural spaces and in almost all moments of human evolution, is, in this case, modified. And, even if it represents, for the young man who has just arrived in the city, a help which he cannot perceive or understand at its true value, the archetype of the old man, through the character of the prince, seems able to help anyone except the protagonist. Thus, by "For twenty-five years he has been marrying girls [...] raising them with French nannies and governesses, then sending them to the best schools, and finally marrying them with dowries," (Dostoevsky, 2019, p. 26) the prince is described as a true civilizing force for all who interact with him, except Arkadi who, in a compulsive search, is unable to satisfy his need for his father's presence.n Therefore we can observe, for example, that apart from the age that is supposed to be almost a symbol of conflict, Arkadi has much more subtle reasons to exaggerate behavior so many times. Angry or embarrassed beyond measure, sometimes by a simple glance, exploding angrily or with an unjustified passion for the topic in question, the teenager shows in a very subtle way that the absence of paternal authority is what facilitated such an ideological development.

On the other hand, the strong image of the father, as an absolute symbol of the pulsation of life, a generator of existence, can be intuited in other Dostoevsky texts. In this context, we will also notice how well the following fragment reminds of the central character from Notes from the Underground: "I am a weak man, who gives in easily to small things [...]. All this comes to me from my lack of control and from the fact that I grew up in the shadows [...], I still prefer to retire to the darkest corner" (Dostoevsky, 2019, p. 31).

The refinement of Dostoevsky's psychological vision is visible through the whole work rather than through a single text. What Mauron proposed, therefore, requires in this case a form of initiation into the complex universe designed in Dostoevsky's work, so that the personal myth, crystallized in the figure of the father, becomes clearer when, beyond Arkadi, we can read as well about the way in which Karamazov's father abandoned his sons, legitimate or not. The absence of authority about which psychoanalysis claimed to play a decisive role in shaping the position of divinity, parents representing figures in which children unconsciously invest sets of beliefs and expectations, models similar human patterns in the work of F.M. Dostoevsky and beyound it. From Arkadi to The Karamazov Brothers, the psychological type projected by the Russian writer is very similar. Distrust is replaced only by the strongest beliefs, which end up alienating the heroes. Ivan and Mitea Karamazov are consumed by the way they perceive the world and themselves, being absolutely convinced of the realities they perceive.

Lost in an atheism whose passion rather suggests the need to believe, Ivan Karamazov, possessor of reason and argument, is at the end of the novel on the verge of an irreversible alienation. Aleoşa, on the 
other hand, chiseled by Christianity and especially by the monastic life, in the control of his own emotions, replaces the non-existent paternal figure with one who, through the tragic destiny reserved for the great characters, leaves him, throwing him into an inexplicable despair which cannot be explained rationally. Fleeing from the monastery after the body of the abbot Zosima begins to decompose, to the general astonishment, Aleoşa succumbs to a despair that can only be understood through the psychological details, essential to the entire Dostoevsky literature. "I do not rebel against God, but I do not want to «accept the world» as he created it, that's all," (Dostoevsky, 1993, p. 584) says little Karamazov when he is seen leaning against a tree outside the monastery, being perhaps vulnerable for the first time, in his role as a savior hero. Surprised in a Gethsemane which was possible only by the feeling of abandonment, intimately known to all the Karamazov brothers, Aleosha suffers a form of temporary "doubling", about which Dostoevsky showed from the beginning of his career, through the novel The Double, published in 1846, that he could understand in its depth. Ready to accept any proposal from the opportunist Rakitin, to enjoy himself with food and drink, even in the company of women, at the opposite pole of the "idea" under which he built his entire existence, guided by the bright figure of the abbot Zosima, the young man sees himself deprived of the most important landmark of its existence.

It is worth mentioning here that the escape of little Karamazov from the monastery takes place in a spiritual context, the chapter The Spirit of Rottenness focusing on the reactions aroused not only by the death of the beloved priest and clergyman, but especially by the way his body enters a natural process, but incompatible with the superficial expectations of the world thirsty for the signs of the divine. In a latent plan, however, Aleoşa rejects a form of organization or, in other words, a destiny which, independent of his will, includes him every time. Perhaps more than all the other Karamazov brothers, Aleosha loses his symbolic father, most of the time. Oscillating between life in the monastery and his father, loving them equally and cherishing them according to Christian dogma, he still loses them both. The abbot dies in a way too specific to the world, while the natural father is killed, which gives rise to the revolt of the young man in the face of relentless events, which he perceives however through the feeling of abandonment. The order of the world, as it is, in which he must unconditionally accept the loss is too much for the young Karamazov.

Therefore, we will notice that Dostoevsky prepared the typology of the abandoned son, who also rebels in the face of the injustice he must bear like a stigma forever, from the moment he projected Arkadi, without a place and landmark in a world so generous with paternal figures. Aleoşa's moment of wandering has a correspondent in most of Arkadi's actions who venture into behaviors far too inappropriate for his desire to succeed socially, getting involved and becoming a role model for everyone else. From the evenings he drank without stopping, to the gambling which Dostoevsky wrote about, projecting his rich and dramatic experience in the field, or hiding in a room where he listens to the conversation of some women, and to the moments in which he loses his temper and scolds those with whom he discusses, the adolescent proves the same acutely felt lack of paternal authority.

The father, on the other hand, to whom the writer's discourse so often turns, as a symbol of vitality, the life-generating principle, has in most of Dostoevsky's texts the same moral features. From The Eternal Husband (Dostoevsky, 1968), where the two rival men, Alexei Ivanovich Velceaninov and Pavel Pavlovich Trusotsky fight for a psychological ascendancy, indifferent even to Liza, Velceaninov's daughter, but raised by Trusotsky, to The Adolescent and, finally, to the last literary masterpiece, The Karamazov Brothers, the image of fatherhood has similar features, and often even identical ones. A form of indifference marks the father's relationship with his children, even if the vital necessities of life are respected from the very beginning but, as a rule, only through intermediaries. Moreover, we will notice that, no matter how alienated the old father Karamazov is, with each of his children, he still chooses to keep Smerdeakov close. The morbid side of the father, using his stepson as a servant, often humiliating him, eventually receives an answer through the revolt of all the sons. The collective guilt, about which Dostoevsky wrote a true poem in his last novel, is with great caution infiltrating the horizon of the Karamazov brothers' feelings. Dmitri openly admits that he wishes the death of Feodor Pavlovici, his father; Ivan leaves the village at a 
particularly tense moment, indirectly leaving room for any intentions towards his father, and Aleoşa, in an illusory kindness, deceives himself and rejects a scenario which inevitably occurs.

The figure of the father, from the mythological register to the unconscious one, impossible to ignore, appears in Dostoevsky's work from the very beginning, even where the age of the heroes or the social dynamics could not suggest or support such an appearance, be it metaphorical. In The Double, Mr. Goliadkin's split becomes an opportunity for Dostoevsky's personal myth to manifest itself, so the writer calls his two heroes "senior Goliadkin" and "junior Goliadkin," referring to the newly appeared double. The replacement of Goliadkin senior, gradual and yet seemingly impossible to stop at any moment, becomes in a psychocritical reading an additional argument for what Freud called unconscious desire specific to the psychology of the son (Freud, 1999, p. 285). It is undoubtedly interesting here the exact way in which for the Russian writer the paternal figure is often the same. The absence of the father provokes a series of actions that alienate the hero in order to purify him, passing him through a ruthless series of experiences for which he was never prepared. Through the simplest process of "overlapping" (Mauron, 2010, p. 33) the texts, as Mauron called it, an imaginative fantasy specific to the symbolism of fatherhood can be observed: "in imagination, the soul which is built plays and rejoices its own history, mixing memories and projects" (Mauron, 2010, p. 106). The overlapping reveals networks which eventually crystallize into fundamental figures or symbols in the economy of any artist's creation.

The novel The Adolescent is an essential landmark when the figure of the father is evoked as part of Dostoevsky's personal myth and because the hero, perfectly designed to serve exactly an unconscious purpose, is trapped in a psychological transition without catharsis. "Although I was over the age of childhood," says Arkadi, caught in the midst of a metamorphosis process, "I still behaved like a child, which proved that in my soul [...] the child's outbursts were still lingering ..." (Dostoevsky, 2019, p. 291). The protagonist's inner turmoil has an obvious echo in the inconsistency of his plans and decisions, permanently subject to inner pressures that he usually perceives only when the effects have become palpable and, as a result, impossible to undo. Faced with impulses for which he finds no correspondent, to understand them, alone because his father's authority has removed him too many times, the hero is faced with human duality, which Dostoevsky seems to have never ceased to write in fact: “... I have failed to unravel this amazing mystery: how can people [...] nurture in their souls the most uplifting ideal with the most odious baseness, and both sincerely full" (Dostoevsky, 2019, p. 379).

The paternal figure and, especially, the name between which he oscillates and which he is ashamed of when he is presented, is, until the end, for the adolescent, an occasion for introspection. The absence of the father and of his support especially, in the most important stages of his existence, imprints the processes of the young man who ventures into society animated by unfounded and often even superficial beliefs. In this sense, we will notice that, in a different form, both in The Adolescent and in The Karamazov Brothers, Dostoevsky proposes works centered on the same symbolic figure of the father:

"When I realized how little I knew about this man, whom I had hurried to condemn, I went to my room in shame. I must confess that it was at that time that I was more perplexed than ever about him. It had never seemed so complicated and enigmatic to me as then. In fact, that was what led me to write this story" (Dostoevsky, 2019, p. 410).

Therefore, the whole process of knowledge revolves around the figure of the father, in which the adolescent constantly invests, hyperbolizing and building puzzles where his imagination could not yet reach. The abrupt end of the novel shows that the enigmatic father is, in fact, in love and even asks the chosen womanto marry him, regardless of the woman who passes as his wife or Arkadi who looks at him as a father.

The renowned researcher Leonte Ivanov said that "Dostoevsky knew how to open the locks that blocked the way to the human soul and to talk to people about general human problems" (Ivanov, 2014). The great themes, among which there is not only the paricide, but also the complex figure of the father, as 
a generator of the creative approach, have attracted countless generations of readers and commentators, ready to reach, through literary work, a new and perhaps deeper knowledge of self. Freud's proposals, expressed in Dostoevsky and the paricide (Freud, 1999, p. 292-294), even if much too oriented towards the pathology of the creator and too little focused on the dimensions of his work, keep the psychoanalyst's vision gleaming. An example of this would be the priority that the researcher gives to the unconscious of the childhood and adolescence of the Russian writer. Freud argued, in relation to the much-discussed Dostoevsky's epileptic seizures, that they would have begun "only after the shocking experience of eighteen years when his father was killed" (Freud, 1999, p. 293).

Today, countless generations of biographers and critics have questioned the dramatic end of the father of one who would become one of the world's most influential writers. However, the death of his father, as the main landmark of the Superego, around the figure of which the future rules and prohibitions of the adult crystallize, cannot pass without consequences, all the more so as the paternal figure is linked to the young man's orientation towards military school,just as, in a very short time, the disappearance of his father also marks a radical change of career, the young Feodor Mihailovici giving up his studies and his career. The epileptic seizures that the writer would have suffered, suggested for Freud, "an identification with a dead person, with a person who has really died or is still alive, but to whom he wishes death" (Freud, 1999, p. 294).

Therefore, Dostoevsky's genius, as Leonte Ivanov suggests, is related to the reality of the human horizon and not to the ideal or desirable. The Russian writer probed so deeply into his personal unconscious that he discovered a universal voice, independent of the language or culture in which he was formed. Furthermore, regardless of the father's destiny, Dostoevsky's paternal figures have similar features, through a visible alienation from any feelings of love, appreciation or even human support.

\section{Bibliography}

Dostoevsky, F.M. (1962). The Idiot, four-part novel, in Romanian by Tamara and Nicolae Gane, preface by G. Fridlender, Literatură Universală Publishing House, București.

Dostoevsky, F. M. (1968). Works, vol. 4, Novels, short stories and stories (1862-1869), literary criticism by Ion Ianoși, Literatură Universală Publishing House, București.

Dostoevsky, F. M. (1993). Frații Karamazov, four-part novel, epilogue included, vol. 2, translated by Ovidiu Constantinescu and Isabella Dumbravă, Cartea Românească Publishing House, București.

Dostoevsky, F. M. (2018). Letters I (1837-1859), edition, translation, notes and introductory study by Leonte Ivanov, Polirom Publishing House, Iași.

Dostoevsky, F.M. (2019). Adolescentul, translated from Russian by Emma Beniuc, Art Publishing House, București.

Eliade, M. (1994). Imagini și simboluri. Eseu despre simbolismul magico-religios, preface by Georges Dumézil, traducere de Alexandra Beldescu, Humanitas Publishing House, București.

Freud, S. (1999). Opere, vol. 1, Eseuri de psibanaliză aplicată, translation by Vasile Dem. Zamfirescu, Trei Publishing House, București.

Ivanov, L. (2014). Două din premisele „marii literaturi”, in “Analele Științifice ale Universității «Al. I. Cuza » Iași”, section III-e, tome LX, p. 157-161.

Mauron, Ch. (2010). De la metaforele obsedante la mitulpersonal, translated from French by Ioana Bot, Dacia Publishing House, Cluj-Napoca.

Vlad, C. (1932). Mihail Eminescu din punct de vedere psihanalitic [Mihail Eminescu from a psychoanalytic point of view], Cartea Românească Publishing House, București. 